\title{
Analysis on the muscle activity of antebrachial area at the iron swing of male high school golf players
}

\author{
Oh Cheong Hwan, Hong Soo Young ${ }^{*}$, Shin Eui Su, Bea Jae Hee \\ From 4th Congress of the International Foot and Ankle Biomechanics (i-FAB) Community \\ Busan, Korea. 8-11 April 2014
}

\section{Introduction}

The purpose of this study is to provide systematic as well as scientific foundational data through 3D image analysis and electromyography (EMG) on male high school golf players' \#7 iron swing.

\section{Methods}

The subjects selected for the experiment of this research were one player who had won in the male high school golf game and seven players whose golf career lasted for over five years. And their age (years) was $19.00 \pm 0.00$, stature $(\mathrm{m})$ was $1.73 \pm 3.29$, body mass $(\mathrm{Kg})$ was 79.00 \pm 13.25 , and career (years) was $7.7 \pm 1.72$. The equipment used for this research for photographing was nine infrared high-speed cameras (Motion Master 100, KOR), and the Kwon3d XP program was utilized for 3D motion analysis. And electromyography (EMG) (Tellemyo $2400 \mathrm{GT}$, USA) was used to analyze their right and left arms' radial extensor of wrist and radial flexor of wrist muscle activity. Also, SPSS 21.0 was employed to conduct independent T-test.

\section{Results and discussion}

Total time consumed for the male high school golf players' \#7 iron swing was $0.35 \pm 0.01 \mathrm{~S}$. Advanced researches targeting professional golf players report that total time consumed at \#7 iron swing is $0.33 \pm 0.01 \mathrm{~S}$; thus, there is $0.02 \mathrm{~S}$ difference between amateur and professional golf players. This seems to be resulted from difference in the experimental environment, and the result is similar to that of advanced researches.

\footnotetext{
* Correspondence: hsy34255@hanmail.net

Physical Education, Chungnam National Univ., Gung-dong, Yuseong-gu,
} Daejeon, 305-764, Korea

\section{Conclusion}

Therefore, they tend to use their right arm's radial extensor of wrist and radial flexor of wrist more at the golf swing. This means that they use their right arm's antebrachial area for hitting so that they can hit the ball more powerfully. If further analysis is done in consideration of each

The displacement of the center of the body was found to be $0.02 \mathrm{~m}$ in the pre- and post-variable $\mathrm{X}$-axis. And a $\mathrm{Z}$-axis. Therefore, according to the result of comparing them with professional golf players in advanced researches, the pre- and post-variable $\mathrm{X}$-axis indicated showed $0.01 \mathrm{~m}$ difference averagely, and next, the horizontal and vertical variable $\mathrm{Z}$-axis had no difference as average 0 . This implies that professional golf players tend to hit Kim Jae-sam (2009)'s research reports that at the \#7 iron swing of professional golf players, the club head's synthetic rate was found to be $25.73 \pm 0.33 \mathrm{~m} / \mathrm{s}$ at the impact (E5). But in this research, it was calculated as $25.63 \pm 1.25 \mathrm{~m} / \mathrm{s}$ at the faster than amateur golf players.

Kim Chang-uk and Pak Jong-jin (2001)'s research compares five high school players with the club by analyzing the muscle activity of their arms at \#7 iron golf swing. cle groups, there was no statistically significant difference found; however, in this research, at the \#7 iron golf swing of male high school golf players, the right arm's radial extensor of wrist and radial flexor of wrist were higher than the left arm's ( $p>001)$. 
individual's characteristics, it will help improve their performance in the game.

Published: 8 April 2014

\section{Reference}

1. Chang ook Kim, Jong Jin Park: Analysis of EMG distribution or loading of arm muscle on golf swing. Journal of Sport Biomechanics 2001, 11(1):13-26.

doi:10.1186/1757-1146-7-S1-A112

Cite this article as: Hwan et al:: Analysis on the muscle activity of antebrachial area at the iron swing of male high school golf players. Journal of Foot and Ankle Research 2014 7(Suppl 1):A112.

Submit your next manuscript to BioMed Central and take full advantage of:

- Convenient online submission

- Thorough peer review

- No space constraints or color figure charges

- Immediate publication on acceptance

- Inclusion in PubMed, CAS, Scopus and Google Scholar

- Research which is freely available for redistribution

Submit your manuscript at www.biomedcentral.com/submit 